\title{
PEMBELAJARAN MENULIS TEKS ARGUMENTASI BERBASIS STRATEGI ROLE AUDIENCE FORMAT TOPIC (RAFT) BERBANTUAN MEDIA VIDEO PERISTIWA AKTUAL PADA MAHASISWA FAKULTAS EKONOMI UNIVERSITAS MUHAMMADIYAH PURWOKERTO
}

\author{
Isnaeni Praptanti \\ Pendidikan Bahasa dan Sastra Indonesia, \\ Univeristas Muhammadiyah Purwokerto \\ Email: isnaenip@gmail.com
}

\begin{abstract}
Abstrak
Penelitian ini bertujuan untuk mengetahui adanya pengaruh strategi pembelajaran Role Audience Format Topic (RAFT) berbantuan video aktual dalam meningkatkan kemampuan menulis teks argumentasi mahasiswa Fakultas Ekonomi program studi Manajemen Universitas Muhammadiyah Purwokerto. Jenis penelitian adalah eksperimen dengan desain eksperimental yang digunakan adalah randomized pre-test- post control group design. Ada dua kelompok dalam Penelitian ini yaitu satu kelompok eksperimen dan satu kelompok control kemudian masing-masing kelompok diberi perlakuan prates dan pascates. Penelitian dilaksanakan di kelas E pada semester genap tahun 2019/2020. Subjek berjumlah 32 mahasiswa terbagi dalam kelompok eksperimen dan kelompok kontrol. Selama masa pembelajaran mahasiswa diberi pretest dan posttest dengan nilai rata-rata pretest kelompok eksperimen sebesar 58,32 dan kelompok kontrol 44,99. Sedangkan nilai rata-rata posttest kelompok eksperiment sebesar 87,49 dan kelompok kontrol 69,57. Berdasarkan hasil uji t terlihat hasil t hitung 6.378 lebih dari t table 2.042. Hal ini menandakan bahwa ada perbedaan kemampuan mahasiswa dalam menulis teks argumentasi yang signifikan berdasarkan uji t. Penggunakan metode RAFT berbantuan video aktual efektif meningkatkan kemampuan menulis teks argumentasi.
\end{abstract}

Kata kunci: strategi pembelajaran, RAFT, video actual

\begin{abstract}
This study aims to determine the effect of the Role Audience Format Topic (RAFT) learning strategy assisted by actual video in improving the ability to write argument text of students of the Faculty of Economics, Management study program, Muhammadiyah University of Purwokerto. This type of research is an experiment whit the experimental design used is the randomized pre-test-post control group design. There were two groups in this study, namely one experimental group then each group was given the pretest and posttest treatment. The research was conducted in class $E$ in the even of 2019/2020. The subjects were 32 students devided into the experimental group and the control group. During the learning period students were given a pretest and posttestwhit an average pretest score of the exsperimental group of 58.32 and the control grup 44.99, while the posttest average score of the experimental group was 87.49 and the control was 69.57. based on the results of $t$ count 6.378 are more than $t$ table of 2.042. this indicates that there is a significant difference in the students ability to write argumentative text based on the t test. Using the actual videoassisted RAFT method effectively improves the ability to write argumentation text.
\end{abstract}

Keywords: learning strategies, RAFT, actual video 


\section{PENDAHULUAN}

Dalam pendidikan, bahasa memiliki peran yang sentral dalam mengembangkan intelektual, sosial, dan emosional mahasiswa, serta merupakan penunjang keberhasilan dalam mempelajari materi pada bidang studi. Pembelajaran bahasa diharapkan mampu membantu mahasiswa berkomunikasi dalam kehidupan, mengemukakan pikiran dan perasaan, serta menggunakan imajinasi dan kreativitasnya menghasilkan sebuah karya. Pembelajaran bahasa Indonesia diberikan pada seluruh jenjang pendidikan dari tingkat rendah hingga tingkat tinggi. Sesuai dengan pendapat tersebut bahwa bidang-bidang pembelajaran bahasa Indonesia terdapat empat keterampilan berbahasa yang harus dikuasai oleh peserta didik, yakni menyimak, berbicara, membaca, dan menulis (Tarigan, 2008:1)

Seiring perkembangan dan kemajuan teknologi keterampilan menulis akan menggeser pandangan tentang kecendekiaan seseorang. Hal tersebut senada dengan pendapat Tarigan (2008: 4) yang menyatakan bahwa keterampilan menulis dapat dikatakan sebagai salah satu ciri dari seseorang yang terpelajar atau bangsa yang terpelajar. Tolak ukur kecendekiaan seseorang dapat dilihat dari kualitas tulisan yang dihasilkan. Menulis menjadi kegiatan aktif produktif, serta mampu menunjukkan eksistensi diri (Apryliana, 2019). Menulis merupakan suatu kegiatan yang ekspresif dan produktif, karena didalamnya terdapat proses kreatif memindahkan gagasan ke dalam lambang-lambang tulisan. Oleh karena itu, menulis merupakan kemampuan yang paling sulit dikuasai, karena perwujudan bentuk komunikasi tidak langsung yang erat hubungannya dengan kemampuan membaca (Darmadi, 1996: 2). Menulis tidak sekedar menyampaikan gagasan atau ide semata, namun juga menunjukkan kedudukan akademis seseorang. Menulis adalah segenap rangkaian-rangkaian kegiatan seseorang dalam mengungkapkan gagasan dan menyampaikannya dalam bentuk tulis kepada masyarakat pembaca untuk dipahami (Gie, 2002:3).

Melalui argumentasi, penulis berusaha merangkaikan fakta-fakta sedemikian rupa sehingga ia mampu menunjukkan apakah suatu pendapat atau suatu hal tertentu itu benar atau tidak. Argumentasi merupakan dasar yang paling fundamental dalam ilmu pengetahuan dan dalam dunia ilmu penge tahuan, argumentasi itu tidak lain dari pada usaha untuk mengajukan bukti atau mengemukakan kemungkinan kemu ngkinan untuk menyatakan sikap atau pendapat mengenai suatu hal. Kemampuan argumentasi sangat penting terutama bagi para mahasiswa sebagai dasar untuk memecahkan berbagai permasalahan (Praptanti, 2017:2). Saat ini, perkembangan menulis di setiap jenjang pendidikan masih tergolong rendah. Berbagai faktor menjadi pemicunya. Salah satu faktor yang memp engaruhi adalah kurangnya minat mahasiswa dalam kegiatan membaca, dan tingkat kompleksitas kegiatan menulis itu sendiri. Kegiatan menulis kerap menjadi pembelajaran yang membosankan. Hal tersebut disebabkan pula bahwa kegiatan menulis mengggabungkan tiga keterampilan sekaligus sebelum mengakh irinya dengan kegiatan menulis.Ketiga ke giatan tersebut, yaitu mendengarkan, membaca, dan berbicara Fenomena tersebut ternyata disertai degan berbagai masalah yang muncul dan dihadapi mahasiswa. Pertama, berkaitan dengan perasaan takut memulai dan takut membuat kesalahan sehingga mahasiswa menganggap bahwa kegiatan menulis merupakan pekerjaan yang sangat sulit. Mahasiswa ditingkat perguruan tinggi (mahasiswa) kerap mengalami kebingungan untuk memulai kegiatan menulis, terutama kegiatan menulis dalam bentuk argumentasi. Kegiatan menulis 
teks argumentasi kerap memberikan kesulitan bagi mahasiswa dalam mengungkapkan argumen mereka ke dalam bentuk tertulis. Mahasiswa masih kebingungan dengan hal-hal yang perlu mereka tuliskan untuk mengawali tulisan teks argumentasi. Mahasiswa masih kurang memahami struktur teks argumentasi.Mahasiswa mengalami kesulitan dalam pengorganisasian ide sebuah tulisan yang arahnya dapat diikuti oleh pembaca. Kesulitan lainnya berkaitan dengan penggunaan bahasa yang digunakan dalam sebuah tulisan.

Permasalahan-permasalahan

tersebut harus disikapi dengan usaha untuk mengatasinya. Salah satunya adalah dengan menerapkan strategi pembelajaran yang tepat dalam pembelajaran menulis, dalam hal ini difokuskan pada pembelajaran argumentasi. Ada beberapa alternatif strategi pembelajaran yang dapat digunakan untuk meningkatkan kemampuan menulis argumentasi. Namun, setiap strategi pembelajaran mempunyai tingkat keefektifan yang berbeda. Oleh karena itu, perlu dicari dan dikembangkan strategi pembelajaran yang efektif dalam meningkatkan keterampilan menulis. Salah satu strategi yang dapat digunakan, yaitu strategi RAFT (Role Audience Format Topic). RAFT (Role Audience Format Topic) merupakan strategi yang dikembangkan oleh Carol Santa pada tahun 1988 (Ruddell, 2005L 288). Strategi ini dapat digunakan untuk meningkatkan kemampuan mahasiswa dalam pembelajaran menulis argumentasi. Strategi ini digunakan untuk meningkatkan kemapuan menulis mahasiswa dengan pemberian tugas sesuai selera dan mengubah persepsi mahasiswa dari menulis topik dan kejadian. Mahasiswa dapat mengembangkan topik dari tema yang sudah disediakan untuk dituangkan dalam tulisan argumentasinya.
Strategi RAFT (Role Audience For mat Topic) dapat memudahkan mahasiswa dalam memunculkan dan menuangkan ide ke dalam tulisan melalui proses tukar pendapat dari kegiatan diskusi yang dilakukan. Dalam kegiatan diskusi tersebut, mahasiswa mengeksplorasi tema menjadi topik-topik yang lebih spesifik serta menggali fakta, data, dan argumen-argumen yang dapat disampaikan untuk meyakinkan pembaca. Selanjutnya, mahasiswa mengkonversinya ke dalam bentuk tulisan argumentasi.

Selain itu, kemajuan ilmu pengetah uan dan teknologi, khususnya teknologi informasi sangat berpengaruh terhadap penyusunan dan implementasi strategi pembelajaran. Melalui kemajuan tersebut seorang dosen dapat menggunakan berbagai media sesuai dengan kebutuhan dan tujuan pembelajaran. Dengan menggunakan media komunikasi bukan saja dapat mempermudah dan mengefektifkan proses pembelajaran, akan tetapi juga bisa membuat proses pembelajaran lebih menarik. Media pembelajaran merupakan seluruh alat dan bahan yang dapat dipakai untuk mencapai tujuan pendidikan, seperti radio, televisi, buku, Koran, majalah, dan sebagainya (Rossi dan Breidle, 1966:3).

Media yang dapat digunakan untuk menggali keterampilan mahasiswa menulis teks argumentasi berbasis strategi RAFT (Role Audience Format Topic) dapat berupa media audiovisual, yakni menggunakan video. Penayangan video dapat mengarah pada video hal- hal atau peristiwa-peristiwa yang aktual sehingga akan lebih menarik dikalangan mahasiswa. Dalam dunia pendidikan atau pengajaran media dapat digunakan dan diarahkan untuk mempermudah mahasiswa belajar dalam upaya memahami materi pelajaran. Berdasarkan alasan-alasan tersebut, penelitian ini akan berfokus pada menguji keefektifan penggunaan strategi RAFT (Role 
Audience Format Topic) berbantuan media video peristiwa aktual untuk meningkatkan kemampuan menulis teks argumentasi pada mahasiswa Ekonomi Manajemen Semester 4 tahun 2020.

Berdasarkan latar belakang di atas dapat dirumuskan permasalahan, antara lain: (1) Bagaimanakah kemampuan menulis teks argumentasi di kelompok eksperi- men menggunakan strategi RAFT berbantuan media video peristiwa aktual? (2) Bagaimanakah kemampuan m enulis teks argumentasi dikelompok kontrol menggunakan strategi Ceramah berbantuan media gambar? (3) Apakah terdapat perbedaan yang signifikan mengenai kemampuan menulis teks argumentasi di kelompok eksperimen dengan menggunakan strategi RAFT berbantuan media video peristiwa actual dengan kemempuan menulis teks argumentasi menggunakan strategi ceramah berbantuan media gambar?

Berdasarkan latar belakang dan permasalahan di atas, tujuaan dari penelitian ini adalah untuk mengetahui keefektifan strategi RAFT berbantuan video peristiwa aktual dalam pembelajaran menulis teks argumentasi pada mahasiswa Ekonomi Manajemen Semester 4 Universitas Muhammadiyah Purwokerto tahun 2020. Penelitian ini diharapkan akan bermanfaat: bagi mahasiswa hasil penelitian ini diharapkan dapat mening- katkan kemampuan menulis, terutama dalam menulis teks argumentasi. Dapat memberikan pengalaman menulis secara langsung, serta mampu membuat mahasiswa menuangkan pendapat- pendapat mereka kedalam bentuk tertulis. Luaran penelitian ini adalah model pembelajaran menulis dan media pembelajaran menulis, artikel dan Hak Cipta.

Menulis memiliki pengertian yang beragam. Abidin (2012) berpendapat bahwa menulis adalah sebuah proses berkomunikasi secara tidak langsung antara penulis dan pembaca. Sebuah tulisan dibuat untuk dipahami maksud dan tujuannya sehingga proses yang dilakukan tidaklah sia-sia. Dalam sudut pandang lain menulis dapat pula dikatakan sebagai kegiatan mereaksi, artinya menulis adalah proses mengemukakan pendapat atas dasar masukan yang diperoleh penulis dari berbagai sumber gagasan yang tersedia. Menulis merupakan suatu keterampilan berbahasa yang dipergunakan untuk berkomunikasi secara tidak langsung, secara tidak tatap muka dengan orang lain (Tarigan, 2008: 3). Akhadiah (1999) memandang bahwa menulis adalah sebuah proses, yaitu proses penugasan gagasan atau ide ke dalam bentuk bahasa tulis yang dalam praktiknya proses menulis diwujudkan dalam beberapa tahapan yang merupakan satu sistem utuh.

Argumentasi adalah suatu bentuk retorika yang berusaha untuk mempengaruhi sikap dan pendapat orang lain agar percaya dan bertindak sesuai dengan apa yang diinginkan oleh penulis atau pembaca (Keraf, 2010: 3). Melalui argumentasi penulis berusaha menyodorkan fakta-fakta yang ada sehingga mampu menunjukkan kebenaran suatu pendapat. Sementara, Semi (2007: 74) menjelaskan bahwa teks argumentasi adalah tulisan yang bertujuan meyakinkan atau membujuk pembaca untuk sependapat berdasarkan fakta dan data yang diberikan oleh penulis. Argumentasi pada dasarnya adalah bagian dari eksposisi karena sifatsifat tulisan eksposisi terdapat juga dalam tulisan argumentasi Sifat khusus yang dimiliki teks argumentasi adalah untuk meyakinkan atau membujuk pembaca agar menerima pandangan penulis. Senada dengan pendapat tersebut, Alwasilah (2005: 116) mendefinisikan

argumentasi sebagai karangan atau teks yang membuktikan kebenaran atau ketidakbenaran dari sebuah pernyataan (statement). Keraf (2010: 104-107) menjelaskan bahwa tulisan argumentasi pada prinsipnya terdiri atas tiga bagian, yaitu pendahuluan, tubuh argument, 
kesimpulan. Alwasilah (2005: 117) menyebutkan secara terperinci mengenai komponen dalam sebuah teks argumentasi, yiatu (1) Introduction berisi Pendahuluan untuk menarik minat atau perhatian pembaca, dan memperkenalkan subjek pembahasan. (2) Tesis adalah peryataan ihwal posisi (sikap) terhadap suatu isi. Pembaca digiring oleh penulis untuk menyetujui tesis atau preposisi (pro-posisi, yakni memihak sebuah posisi). (3) Edvidence atau proofs berisikan bukti-bukti yang disajikan untuk sebuah tesis. (4) Opposing arguments berisikan argument tandingan yang perlu disajikan sebeum penulis menyampaikan argumentasinya sendiri. (5) Conclusion berupa kesimpulan untuk mengukuhkan yang sebelumnya disebut.

Langkah-langkah menulis teks argumentasi, yaitu (1) menentukan topik permasalahan, (2)merumuskan tujuan argumentasi, (3) mengumpulkan bahan berupa bukti, fakta, dan data yang sesuai dengan topik, (4) menuangkan gagasan menjadi kerangka tulisan, (5)mengembangkan kerangka menjadi tulisan utuh teks argumentasi, (6) menghadiri penggunaan kata atau istilah yang terlalu umum atau ragu, dan (7) merevisi baginbagian yang tidak perlu.

RAFT merupakan pengembangan dari model bermain peran (role playing). Role playing disini merupakan sebuah model pengajaran yang berasal dari dimensi pendidikan individu maupun sosial. Model ini membantu masingmasing siswa untuk menemukan makna pribadi dalam dunia sosial mereka dan membantu memecahkan dilema pribadi dengan bantuan kelompok. Dalam dimensi sosial, model ini memudahkan individu untuk bekerja sama dalam menganalisis kondisi sosial, khususnya masalah kemanusiaan. Esensi role playing adalah keterlibatan partisipan dan peneliti dalam situasi permasalahan dan adanya keinginan untuk memunculkan resolusi damai serta memahami apa yang dihasilkan dari keterlibatan langsung ini. Role playing berfungsi untuk (1) mengeksplorasi perasaan siswa, (2) mentransfer dan mewujudkan pandangan mengenai perilaku, nilai, dan persepsi siswa, (3) mengembangkan skill pemecahan masalah dan tingkah laku, dan (4) mengeksplorasi materi pelajaran dengan cara yang berbeda.

RAFT (Role Audience Format Topic) merupakan strategi yang dikembangkan oleh Carol Santa pada tahun 1988 (Ruddell, 2005: 288). Strategi ini digunakan untuk meningkatkan kemampuan menulis mahasiswa dengan memberikan tugas sesuai selera mahasiswa dan mengubah persepsi mahasiswa dari menulis topik dan kejadian. RAFT merupakan akronim dari $\mathrm{R}$ - Role of the writer (who are you); $\mathrm{A}-$ Audience for the writer (to whom are you writing); $\mathrm{F}$ Format of the writing (what form will you writing take); $\mathrm{T}$-Topic of the writing (what are you writing about).

Strategi ini merancang mahasiswa agar dapat memposisikan diri sebagai siapa, untuk siapa, dalam format seperti apa, dan topik spesifikasi apa sebagai bahan untuk menulis. Hal ini bertujuan supaya peserta didik lebih fokus terhadap tulisan yang akan ditulis. Berikut tahapannya.

Langkah 1. Memilih Topik (Selecting the Topic) Setiap mahasiswa membuat dan mengembangkan skema mengenai suatu topik. Sebagai contoh, yaitu korupsi, bencana alam, kekeringan, pemanasan global, UU terbaru, struktur pemerintahan terbaru. Selanjutnya setiap kelompok memilih satu dari subtopic yang dibuat sebagai fokus dari pemilihan topik mereka dan melakukan tukar pendapat serta mencatat pertanyaanpertanyaan yang berkaitan mengenai subtopik tersebut. Setiap kelompok mengulang proses tukar pendapat serta mencatat pertanyaan-pertanyaan tentang subtopik yang lain untuk membuat sebuah kumpulan topik yang mungkin bisa 
ditulis. Kemudian masing-masing kelompok merumuskan sebuah pertanyaan yang akan dijawab dalam sebuah tulisan.

Langkah 2. Mengumpamakan Se buah Peran (Asumming a Role) Dosen memandu mahasiswa melalui proses identifikasi peran dengan bertanya pada masing-masing kelompok untuk melakukan diskusi. Setelah mengeksplor dan menjawab pertanyaan ini, mahasiswa memilih peran mereka.

\section{Langkah 3. Memilih Pendengar}

(Selecting an Audience) Memilih pendengar mengikuti pola yang sama seperti memilih sebuah peran. Pada mahasiswa menggunakan pertanyaan yang telah mereka buat dan peran yang mereka pilih untuk berdiskusi. Ketika ide tidak kunjung muncul, para peserta didik memilih seorang pendengar.

Langkah 4. Memilih Format (Selecting a Format) Ketika memilih sebuah format, mahasiswa harus tahu jenis-jenis format tulisan yang biasanya digunakan penulis. Format berarti merefleksikan sudut pandang dan tujuan dari penulis.

\section{Langkah 5. Mengorganisasi Infor masi dan Menulis (Organizing Information and Writing)}

Tahap yang terakhir dari strategi RAFT bertujuan agar mahasiswa mengumpulkan dan mengorganisasikan informasi terkait topik dan format untuk proses menulis. Dalam pelaksaan tahap-tahap tersebut, tentunya diperlukan bantuan dan bimbingan dari pihak pengajar.

Secara umum media merupakan kata jamak dari "medium", yang berarti perantara atau pengantar. Istilah media juga digunakan dalam bidang pengajaran atau pendidikan sehingga sering kita sebut sebagai media pembelajaran. Media pembelajaran adalah seluruh alat dan bahan yang dapat dipakai untuk mencapai tujuan pendidikan, seperti radio, televisi, buku, koran, majalah, dan sebagainya (Rossi dan Breidle, 1966:3).

Menggunakan media pembelajaran dapat memberikan pengalaman langsung kepada mahasiswa dalam proses pembelajaran. Media pembelajaran memiliki fungsi dan berperan untuk: (a) Menangkap suatu objek atau peristiwaperistiwa tertentu Peristiwa-peristiwa penting atau objek dapat diabadikan dengan foto, film, atau direkam melalui video atau audio, kemudian peristiwa atau objek tersebut dapat disimpan dan digunakan untuk proses pembelajaran. (b) Memanipulasi keadaan, peristiwa atau objek tertentu melalui media pembelajaran dosen dapat menyajikan bahan pelajaran yang bersifat abstrak menjadi konkret sehingga mudah dipahami dan dapat menghilangkan verbalisme. Media pembelajaran bisa membantu menampilkan objek yang terlalu besar yang tidak mungkin dapat ditampilkan di dalam kelas, atau menampilkan objek yang terlalu kecil yang sulit dilihat dengan menggunakan mata telanjang. Media pembelajaran pun dapat menampilkan suatu proses atau gerakan yang terlalu cepat yang sulit diikuti untuk memanipulasi keadaan. (c) Menambah gairah dan motivasi belajar siswa. Penggunaan media pembelajaran dapat menambah motivasi belajar mahasiswa sehingga perhatian mahasiswa terhadap materi pembelajaran dapat lebih meningkat. Sebagai contoh, sebelum menjelaskan materi pelajaran mengenai teks argumentasi, untuk dapat menarik perhatian mahasiswa terhadap topik tersebut, maka dosen dapat memutar video terlebih dahulu mengenai peristiwaperistiwa aktual dan sebagainya.

Secara umum media merupakan kata jamak dari "medium", yang berarti perantara atau pengantar. Istilah media juga digunakan dalam bidang pengajaran atau pendidikan sehingga sering kita sebut sebagai media pembelajaran. Media pembelajaran adalah seluruh alat dan 
bahan yang dapat dipakai untuk mencapai tujuan pendidikan, seperti radio, televisi, buku, koran, majalah, dan sebagainya (Rossi dan Breidle, 1966:3).

Menggunakan media pembelajaran dapat memberikan pengalaman langsung kepada mahasiswa dalam proses pembelajaran. Media pembelajaran memiliki fungsi dan berperan untuk: (a) Menangkap suatu objek atau peristiwaperistiwa tertentu. Peristiwa-peristiwa penting atau objek dapat diabadikan dengan foto, film, atau direkam melalui video atau audio, kemudian peristiwa atau objek tersebut dapat disimpan dan digunakan untuk proses pembelajaran. (b) Memanipulasi keadaan, peristiwa atau objek tertentu. Melalui media pembelajaran dosen dapat menyajikan bahan pelajaran yang bersifat abstrak menjadi konkret sehingga mudah dipahami dan dapat menghilangkan verbalisme. Media pembelajaran bisa membantu menampilkan objek yang terlalu besar yang tidak mungkin dapat ditampilkan di dalam kelas, atau menampilkan objek yang terlalu kecil yang sulit dilihat dengan menggunakan mata telanjang. Media pembelajaran pun dapat menampilkan suatu proses atau gerakan yang terlalu cepat yang sulit diikuti untuk memanipulasi keadaan.(c) Menambah gairah dan motivasi belajar siswa.

\section{METODE PENELITIAN}

Jenis penelitian adalah eksperimen semu. Jenis penelitian eksperimen semu dipilih karena tidak membuat kelompok baru, tetapi menggunakan kelas-kelas sebagaimana adanya. Melibatkan dua variabel yaitu variabel bebas dan variabel terikat. Variabel bebas dalam penelitian adalah strategi pembelajaran yang akan diuji cobakan dan terdiri atas strategi RAFT (X1) dan media pembelajaran (X2), dan variabel terikat adalah kemampuan menulis teks argumentasi mahasiswa Ekonomi Manajemen semester 4 tahun ajaran 2020/2021.
Desain ekperimental yang digunakan dalam penelitian ini adalah rendomized pre-tes- posttest control group design. Terdapat dua kelompok sampel dalam penelitian ini, yaitu satu kelompok eksperimen kelas A ( 16 mhs) dan satu kelompok kontrol kelas B (16 mhs), kemudian masing-masing kelompok diberi perlakuan prates dan pascates. Adapun tahapan penelitian ini mencakup tahap tes awal sebelum perlakuan, tahap perlakuan dan tahap tes akhir setelah perlakuan. Penelitian dilakukan pada mahasiswa Ekonomi Manajemen UMP semester 4 tahun ajaran 2020/2021. Waktu penelitian dimulai pada bulan Februari-Agustus 2020/2021. Instrumen yang digunakan dalam penelitian adalah soal menulis dan lembar penila ian menulis teks argumentasi. Lembar penilaian digunakan untuk menilai hasil karya mahasiswa. Penyusunan instrumen penelitian mengacu pada kisi-kisi lembar penilaian. Teknik analisis data yang digunakan adalah uji-t sampel bebas. Asumsi untuk uji-t sampel bebas sebagai berikut: (1) jika skor thitung baik dihitung dengan varian yang sama atau berbeda menghasilkan skor lebih besar dari tabel dan taraf signifikasi yang sama-sama signifikan, yaitu kurang dari 0,05, hipotesis kerja diterima, (2) jika skor $t_{\text {hitung }}$ baik dihitung dengan varian yang sama atau berbeda menghasilkan skor lebih kecil dari $t_{\text {tabel }}$ dan menghasilkan taraf signifikasi lebih besar dari 0,05, hipotesis kerja ditolak. Berikut ini hipotesis penelitian.

$\mathrm{Ho}=$ Tidak ada perbedaan yang signifikan terhadap keefektifan penggunaan strategi RAFT berbantuan media video peristiwa aktual dalam kegiatan pembelajaran menulis teks argumentasi pada mahasiswa ekonomi manajemen semester 4 UMP.

$\mathrm{Ha}=\mathrm{Ada}$ perbedaan yang signifikan terhadap keefektifan penggunaan strategi RAFT berbantuan media 
video peristiwa aktual dalam kegiatan pembelajaran menulis teks argumentasi pada mahasisw a fakultas ekonomi semester 4 UMP

Berikut ini peta penelitian.

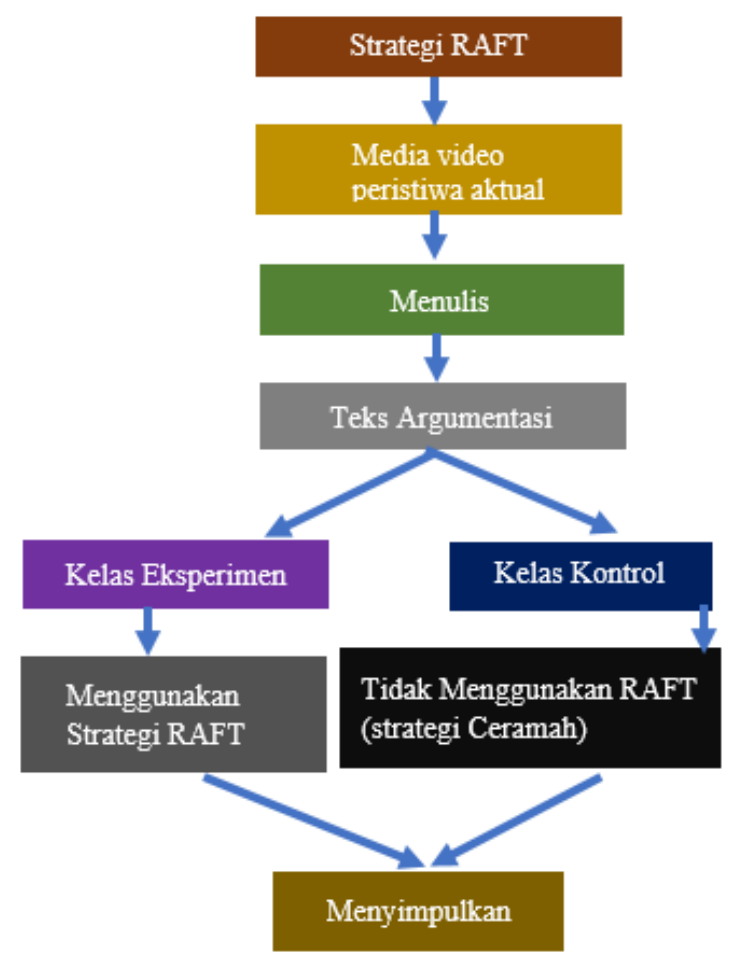

Gambar 1. Peta Penelitian

\section{HASIL DAN PEMBAHASAN}

\section{Hasil Penelitian}

Uji normalitas data dilakukan dengan tujuan untuk mengetahui data yang dihasilkan dari penelitian berdistribusi normal atau tidak. Penghitungan pada uji normalitas data menggunakan bantan software SPSS-20 dengan asumsi data berdistribusi normal jika skor Signifikasi yang dihasilkan lebih besar dari 0,05 Berdasarkan tabel hasil uji normalitas data di atas menunjukkan skor signifikasi yang dihasilkan dari perhitungan, yaitu 0,179. Skor signifikasi yang dihasikan lebih besar dari skor alpha, yakni 0,05. Hal tersebut membuktikan bahwa distribusi data penelitian bersifat normal atau penyebarannya merata. Penyebaran data yang merata menjadi syarat pertama yang wajib dipenuhi dalam penelitian eksperimen semu dengan dua kelas, yaitu kelas eksperimen (uji coba) dan kelas kontrol. Tahap selanjutnya, yakni uji homogenitas data.

Uji homogen pada sebaran data penelitian dilakukan dengan tujuan untuk mengetahui apakah data bersifat sama atau heterogen. Sebaran data dalam penelitian eksperimen semu haruslah bersifat sama. Oleh karena itu, perlu uji homogenitas untuk membuktikannya. Asumsi untuk uji homogenitas, yaitu data bersifat homogen (sama) jika skor signifikasi yang dihasilkan dari perhitungan menunjukkan skor yang lebih besar dari skor alpha, yakni 0,05 . Jika skor hitung menunjukkan lebih besar dari skor alpha 0,05 , artinya sebaran data berifat heterogen (tidak sama). Berikut ini tabel hasil penghitungan uji homogentias.

Tabel 1. Hasil Uji Homogenitas Data

\begin{tabular}{|l|l|l|l|}
\hline $\begin{array}{l}\text { Levene } \\
\text { Statistic }\end{array}$ & df1 & df2 & Sig. \\
\hline .035 & 1 & 30 & .852 \\
\hline
\end{tabular}

Berdasarkan hasil hitung uji homogenitas yang menggunakan bantuan software SPSS.20 menunjukkan bahwa skor signifikasi yang dihasilkan sebesar 0,852 . Skor hitung yang dihasilkan menunjukkan lebih besar dari skor alpha, yaitu 0,05. Artinya, sebaran data yang digunakan dalam penelitian ini bersifat homogen atau sama. Oleh sebab itu, sampel dalam penelitian ini dapat digunakan sebagai gambaran secara luas. Uji homogentis data menjadi syarat kedua untuk memenuhi tahapan analisis data pada jenis penelitian eksperimen semu. Terbuktinya skor uji homogenitas data yang bersifat homogen menunjukkan bahawa penelitian ini dapat melangkah pada tahap analisis data selanjutnya. Hasil pretest kelas eksperimen Kelas 
eksperimen merupakan kelas yang dikenai perlakuan atau tindakan dalam pembelajaran. Kelas eksperimen dipilih dengan tujuan untuk menguji-coba apakah strategi pembelajaran yang diterapkan dapat efektif dan membantu mahasiswa selama perkuliahan. Kelas eksperimen ini dipilih dengan pertimbangan bahwa kelas diambil secara random dengan harapan strategi yang digunakan dapat membantu peserta didik untuk mengikuti perkuliahan dan mencapai pembelajaran yang sebelumnya sudah ditentukan. Berikut ini hasil perhitungan deskriptif pada kelas eksperimen data pretes.

Berdasarkan hasil perhitungan deskriptif yang menggunakan bantuan software SPSS 20 menghasilkan skor, yaitu jumlah data 16 , rerata 8,75 , Std Dev 1,00, Varian 1,000, Range 3, skor minimum 7 dan skor maksimum 10 . Berdasarkan hasil perhitungan tersebut menunjukkan bahwa mahasiswa yang berada di kelas eksperimen memiliki kemampuan belajar dan beradaptasi dengan materi, serta memiliki dasar pengetahuan secara umum terhadap materi teks argumentasi. Oleh karena itu, perlu adanya perlakuan yang lebih mendalam selama pembelajaran guna tercapainya tujuan belajar dari materi menulis teks argumentasi.

Kelas kontrol merupakan kelas yang digunakan sebagai penyeimbang kelas ek sperimen. Kelas kontrol melakukan pembelajaran yang sama, yaitu pembelajaran materi teks argumentasi, namun tidak menerapkan strategi pembelajaran yang sama dengan kelas eksperimen kelas control menerapkan pembelajaran $\mathrm{k}$ onvensional yang kerap dosen mengguna kannya. Kelas kontrol berperan sebagai penyeimbang dan pembanding terhadap hasil uji yang dihalukan pada data posttes setelah kegiatan pembelajran berakhir.

Berdasarkan hasil perhitungan deskriptif yang menggunakan bantuan software SPSS 20 menghasilkan skor, yaitu jumlah data 16 , rerata 6,75 , Std Dev
1,065, Varian 1,133, Range 3, skor minimum 5 dan skor maksimum 8 . Berdasarkan hasil perhitungan deskriptif yang dilakukan pada data dari kelas kontrol menunjukkan bahwa ada perbedaan kemampuan pererta didik dalam memahami dan menguasai materi dasar tentang teks argumentasi. Berikut ini tabel hasil perhitungan komulati dan histogram dari uji pretes pada kelas konrol.

Hasil posttest kelas eksperimen yang berdasarkan hasil perhitungan deskriptif yang menggunakan bantuan software SPSS 20 menghasilkan skor, yaitu jumlah data 16 , rerata 12,94 , Std Dev 1,063, Varian 1,129, Range 3, skor minimum 11 dan skor maksimum 14. Berdasarkan hasil perhitungan tersebut menunjukkan bahwa mahasiswa yang berada di kelas eksperimen memiliki kemampuan belajar, beradaptasi dengan materi, dan belajar sesuai dengan Metode RAFT selama pembelajaran berlangsung. Berikut hasil posttest kelas kontrol yang Berdasarkan hasil perhitungan deskriptif yang menggunakan bantuan software SPSS 20 menghasilkan skor, yaitu jumlah data 16, rerata 10,44, Std Dev 1,153, Varian 1,329, Range 4, skor minimum 9 dan skor maksimum 13. Berikut ini tabel sebaran frekuensi komulatif hasil posttes kelompok control.

Hasil uji-t pada data posttest kelompok eksperimen dan kelompok kontrol yaitu menunjukkan bahwa penghitungan Levene's test untuk menguji homogenitasi data atau perbedaan variasi menghasilkan skor F sebesar 0,147 karena skor signifikasi yang dihasilkan lebih kecil dari skor alpha, maka dapat diartikan terdapat perbedaan varian pada data kemampuan mahasiswa terhadap munulis karangan argumentasi. Terlihat dari hasil t-hitung menghasilkan 6,378 yang lebih besar dari t-tabel yaitu 2,042. Skor Sig hasil uji-t menunjukkan skor sebesar 0,000, hal tersebut membuktikan bahwa adanya perbedaan yang signifikan. Oleh karena itu, menandakan bahwa adanya 
perbedaan kemampuan mahasiswa terhadap menulis agumentasi yang signifikan berdasarkan hasil uji-t. Kemampuan mahasiswa yang menggunakan Metode RAFT selama pembelajaran menulis argumentasi menunjukkan bahwa metode tersebut efektif, serta dapat menjadi solusi bagi pengajar lainnya untuk dapat mengunakan metode ini selama pembelajaran menulis argumentasi atau jenis teks lainnya.

\section{Pembahasan}

Kegiatan menulis menjadi sebuah $\mathrm{k}$ eharusan yang wajib dikuasai oleh mahasiswa, tidak terkecuali mahasiswa Fakultas Ekonomi Universitas Muhammadiyah Purwokerto. Guna meningkatkan kemampuan akademis memerlukan pembelajaran menulis untuk melatih dan membiasakan diri mengungkapka $\mathrm{n}$ gagasan atau ide-ide atau pendapat mereka kedalam bentuk tulisan. Sejalan dengan pendapat Apryliana (2019) menjelaskan bahwa menulis merupakan kegiatan aktif produktif guna menunjang kebutuhan aktualisasi diri. Sependapat dengan Abidin (2012) yang menjelaskan bahwa menulis adalah sebuah proses berkomunikasi secara tidak langsung antara penulis dan pembaca. Sebuah tulisan dibuat untuk dipahami maksud dan tujuannya sehingga proses yang dilakukan tidaklah sia-sia. Dalam sudut pandang lain menulis dapat pula dikatakan sebagai kegiatan mereaksi, artinya menulis adalah proses mengemukakan pendapat atas dasar masukan yang diperoleh penulis dari berbagai sumber gagasan yang tersedia.

Berbagai macam atau jenis tulisan memerlukan pelatihan secara berulangulang, serta berkelanjutan. Salah satu jenis teks yang perlu dikuasai oleh mahasiswa Fakultas Ekonomi Universitas Muhammadiyah Purwokerto adalah jenis teks argumentasi. Sesuai dengan pendapat Keraf (2010: 3) bahwa teks argumentasi adalah suatu bentuk retorika yang berusaha untuk mempengaruhi sikap dan pendapat orang lain agar percaya dan bertindak sesuai dengan apa yang diinginkan oleh penulis atau pembaca. Melalui argumentasi penulis berusaha menyodorkan fakta-fakta yang ada sehingga mampu menunjukkan kebenaran suatu pendapat.

Sementara, Semi (2007:74)

menjelaskan bahwa teks argumentasi adalah tulisan yang bertujuan meyakinkan atau membujuk pembaca untuk sependapat berdasarkan fakta dan data yang diberikan oleh penulis. Oleh karena itu, teks argumentasi diperlu dikuasai ooleh mahasiswa guna membantu mereka untuk mengungkapkan gagasan atau pendapat terhadap fenomena yang terjadi di masyarakat dengan tujuan mempengaruhi pembaca berdasarkan data dan fakta yang sebelumnya telah dicari.

Teks argumentasi dianggap penting bagi mahasiswa dikarenakan teks argumentasi tidak hanya menjadi media guna menuangkan pendapat mereka, namun juga dalam penyusunannya diperlukan riset literatur yang mendalam untu menemukan seluruh bukti dan data dengan tujuan sebagai penguat atas pendapat dan pemikiran mereka yang diharapkan mampu mendapatkan respon positif dari pembaca. Teks argumentasi kerap dimenjadi pilihan utama guna mengungkapkan pendapat seseorang yang tujuannya untuk berpihak pada salah satu pilihan yang terjadi pada fenomena di masyarakat. Oleh karena itu, guna meningkatkan kemampuan menulis mahasiswa Fakultas Ekonomi perlu adanya pembelajaran yang khusus menerapkan strategi tertentu selama kegiatan belajar di kelas. Salah satu strategi yang dapat dipilih, yaitu strategi RAFT (Role, Audience, Format, Topic).

Strategi RAFT belum $\begin{aligned} & \text { pernah } \\ & \text { selama }\end{aligned}$
digunakan
pembelajaran menulis teks argumentasi.
Oleh karena tu, perlu adanya uji coba
terhadap strategi tersebut untuk
mengetahui ingkat keefektifannya.


Strategi RAFT (Role, Audience, Format, Topic) merupakan strategi yang dikembangkan oleh Carol Santa pada tahun 1988 (Ruddell, 2005: 288). Strategi ini digunakan untuk meningkatkan kemampuan menulis peserta didik dengan memberikan tugas sesuai selera siswa dan mengubah persepsi siswa dari menulis topik dan kejadian. RAFT merupakan akronim dari R-Role of the writer (who are you); $\mathrm{A}$ - Audience for the writer (to whom are you writing); F - Format of the writing (what form will you writing take); $\mathrm{T}$ - Topic of the writing (what are you writing about). Strategi ini merancang peserta didik agar dapat memposisikan diri sebagai siapa, untuk siapa, dalam formt seperti apa, dan topik spesifikasi apa sebagai bahan untuk menulis. Hal ini bertujuan supaya peserta didik lebih fokus terhadap tulisan yang akan ditulis.

Penelitian yang dilakukan terhadap mahasiswa Fakultas Ekonomi yang menerapkan Strategi RAFT dalam pembelajaran menulis teks argumentasi dilakukan selama satu semester. Kegiatan penelitian ini bertujuan untuk mengetahui keefektifan dalam penggu naan strategi RAFT selama pembelajaran menulis teks argumentasi. Peneliian ini menghasilkan data-data berupa angka yang telah diuji menggunakan bantuan software SPSS versi 20. Hasil dari uji statistic yang dilakukan menunjukkan bahwa strategi RAFT terbukti efektif digunakan sebagai strategi pembelajar an menulis teks argumentasi. Keefektifan tersebut dilihat dari hasi uji-t yang dilakukan terhadap skor post-tes kelas eksperimen dan kelas kontrol. Pembuktian keefektifan tersebut tidak hanya terlihat pada hasil uji beda yang telah dilakukan, namun juga terlihat pada peningkatan pada skor kemampuan menulis kelas eksperimen yang menggunakan strategi RAFT selama pembelajara. Perubahan lainnya yang terjadi selama pembelajaran, yaitu adanya praktik nyata yang dilakukan oleh mahasiswa selama pembelajaran menulis teks argumentasi, adanya kemampuan berpendapat yang meningkat selama pembelajaran, adanya keefektifan positif dari respon peserta didik dalam memberikan pendapat mereka secara lisan, serta kemampuan mengungkapkan gagasan kedalam bentuk tulisan lebih meningkat. Hal tersebut dibuktikan dari hasil tulisan mereka yang lebih baik dari saat melakukan pre-tes atau tes awal yang dilakukan sebelum pembelajaran.

Mahasiswa telah mampu menyusun kalimat sesuai dengan benar, semakin banyak data dan fakta yang mereka gunakan sebagai penunjang pendapat, meningkatnya kemampua n dalam pemilihan kosakata, adanya perbaikan dalam penggunaan tanda baca, adanya perubahan sikap positif dari mahasiswa, yakni mampu mengungkapkan pendapat mereka secara terbuka berdasarkan data dan fakta. Oleh karena itu, strategi RAFT terbukti efektif dalam pembelajaran menulis teks argumentasi. Diharapkan dari hasil penelitian ini, dapat menjadi salah satu strategi rekomendasi yang dapat digunakan dalam pembelajaran menulis, baik ditingkat mahasiswa ataupun peserta didik ditingkan SMP/SMA. Meskipun telah terbukti efektif, perlu adanya penelitian lanjutan yang dapat membuktikan bahwa strategi RAFT dapat terbukti efektif pada pembelajaran menulis teks lainnya.

\section{KESIMPULAN}

Berdasarkan hasil penelitian, dapat disimpulkan bahwa melalui penerapan strategi Role Audience Format Topic (RAFT) untuk mahasiswa Fakultas Ekonomi UMP mempunyai pengaruh dalam peningkatan keterampilan menulis teks argumentasi. Hal ini dapat dilihat dari hasil yang dicapai mahasiswa pada pre test dan post test. Pada nilai pre test rata-rata nilai yang dicapai pada nilai pre test adalah 58,32 dengan nilai tertinggi yang diperoleh mahasiswa 66,6 sedangkan nilai terendahnya 53,33. Sedangkan nilai post 
test rata-rata siswa 87,49 dengan nilai tertinggi mahasiswa 93,33 dan nilai terendah 73,33. Berdasarkan standart kriteria penilaian termasuk kategori baik.

\section{DAFTAR PUSTAKA}

Abidin, Yunus.2012. Pembelajaran Bahasa Berbasis Pendidikan Karakter. Bandung: Refika Aditama.

Akhadiah, Sabarti. 1999.Pembinaan Kemampuan Menulis Indonesia. Jakarta: Erlangga.

Alwasilah, A. Chaedar. 2005. Pokoknya menulis Cara Baru Menulis dengan Metode Kolaborasi. Bandung: PT Kiblat Buku Utama.

Apryliana, Agnes.2019. Pengembangan Modul pembelajaran Menulis Berbasis Strategi Think-TalkWrite. Jurnal Bahastra, pp. 108117.

Darmadi, Kaswan.1996. Meningkatkan Kemampuan Menulis (Pandu-an untuk Mahasiswa dan Calon Mahasiswa). Yogyakarta: ANDI.
Huda, Miftahul. 2017. Model-Model Pengajaran dan Pembelajaran Yogyakarta: Pustaka Pelajar.

Keraf, Gorys. 2010.Argumentasi dan Narasi Komposisi Lanjutan III. Jakarta: Gramedia.

Praptanti, Isnaeni. 2017. Analisis Kemam $\neg$ puan Menulis Argumen-tasi Pada Makalah Ilmi-ah Mahasiswa Farmasi Universitas Muhammadiyah Purwokerto. Purwokerto:UMP

Ruddell, Martha rapp. 2005.Teaching Content reading and Writing. USA: Wiley. Semi, Atar. 2007. Dasar-dasar Keterampilan Menulis. Bandung: Angkasa.

Sanjaya, Wina. 2007. Strategi Pembelajar $\neg$ an Berorientasi Standar Proses Pendidikan. Jakarta: Kencana. .2007. Kajian Kurikulum dan Pembelajaran. Bandung:UPI.

Tarigan, Henry Guntur. 2008.Menulis sebagai Suatu Keterampilan berbahasa. Bandung: Angkasa. 